\title{
Gratisaviserne som en politisk ressource
}

\section{AF ASKE KAMMER}

Selvom gratisaviserne i løbet af en ganske kort årrække blev nogle af landets mest læste aviser, er den danske forskning i denne avistype stadig uhyre begrænset, især set fra et indholdsanalytisk perspektiv. I denne artikel præsenteres resultaterne af en kvantitativ indholdsanalyse af gratisavisernes politiske stof i sammenligning med det tilsvarende stof i en morgenavis og en tabloidavis. Analysen er gennemført med udgangspunkt i de tre opstillede parametre 'monitorering', 'forståelse' og 'adgang', som - argumenteres der for - kan være et udtryk for, hvorvidt et nyhedsmedie kan siges at udgøre en politisk ressource.

Siden 2001, hvor først metroXpress og siden Urban blev introduceret på det danske avismarked, har gratisaviserne spillet en vigtig rolle i såvel det danske pressesystem som i mange danskeres forbrug af nyhedsmedier. Gratisaviserne har eksempelvis været medvirkende til at vende de konsekvent faldende oplags- og læsertal, som ellers har præget avisbranchen gennem en længere årrække. En større kortlægning af danskernes avislæsning viser således, at avisernes samlede dækning på grund af gratisaviserne steg med omtrent 10 procent i perioden 2000-2004, mens den omvendt faldt med omtrent 10 procent i samme periode, hvis gratisaviserne ikke medregnes i statistikken (Advice Analyse og Strategi 2005: 7). I 2006 satte gratisaviserne endvidere pressesystemet på den anden ende, da både Dato, 24timer og Nyhedsavisen begyndte at udkomme i løbet af sensommeren og efter året. Dato lukkede dog igen efter mindre end et år, da avisen i 
foråret 2007 fusionerede med 24timer, og efter en noget tumultarisk tilværelse (skildret i Skyum-Nielsen et al. 2009) udkom Nyhedsavisen for sidste gang i august 2008 (se desuden Minke 2008). Ifølge TNS Gallups målinger af læsertal er de tre tilbageværende gratisaviser dog i skrivende stund stadig blandt Danmarks mest læste aviser, om end den finansielle krise har reduceret disse annoncefinansierede avisers oplagstal markant. Alt dette til trods har den hidtidige forskning dog kun udvist en meget behersket interesse $\mathrm{i}$ at undersøge indholdet i gratisaviserne. I en dansk sammenhæng er den hidtil eneste videnskabelige indholdsanalyse af gratisaviserne således Unni From og Nete Nørgaard Kristensens gennemgang af disse avisers kulturstof (From \& Kristensen 2007), men også internationalt er omfanget af disse indholdsanalyser ganske begrænset (se dog Bakker 2007a og Wadbring 2003 for eksempler).

Fraværet af indholdsanalyser af gratisaviserne er så meget desto mere overraskende, når denne avistypes udbredelse i de befolkningsgrupper, som ikke tidligere læste avis (Bakker 2007b: 67-68, Wadbring 2007a, 2007b), tages i betragtning. En nærmere analyse af de danske avisers læsersammensætning viser ligeledes, at selvom gratisaviserne læses af alle på tværs af sociale og klassemæssige skel, udgør de en relativt større andel af den samlede avislæsning i de befolkningsgrupper, som har de laveste lønninger, de korteste uddannelser og de lavest rangerende stillinger (Kammer 2009: 12 ff.) - altså de efter forskellige målestokke mindst ressourcestærke befolkningsgrupper i samfundet. I den udstrækning, man antager, at der er en positiv sammenhæng mellem brugen af nyhedsmedier og demokratisk deltagelse (hvilket eksempelvis Nick Couldry, Sonia Livingstone og Tim Markham finder statistisk belæg for (Couldry et al. 2007: 153 ff.)), kan læsning af gratisaviser i de svagere befolkningsgrupper formodes at skabe en mere inklusiv politisk offentlighed. Dette forudsætter imidlertid som minimum, at gratisaviserne rent faktisk indeholder politisk stof.

På denne baggrund præsenterer denne artikel resultaterne af en kvantitativ indholdsanalyse af gratisavisernes politiske stof ud fra en hypotese om, at dette stof er af en sådan karakter, at det kan forstås som en politisk ressource. Det er dog ikke undersøgt 
her, hvordan gratisavisernes politiske stof bruges af læserne, eller hvilken effekt det har.

\section{Hvad er en politisk ressource?}

I hverdagens sprogbrug er en ressource noget, som står til rådighed, og som kan tages i brug som et middel til at nå et mål, og begrebet er således behæftet med en forestilling om nytte, brugsværdi og anvendelsesorientering. Formuleret lidt mere præcist og med udgangspunkt i sociologisk teori er en ressource det, som sætter en aktør i stand til at handle (Giddens 1979: 92), og en politisk ressource må følgelig være det, som kan tænkes at være medvirkende til at sætte en borger i stand til at handle politisk ved at varetage sit politiske medborgerskab.

Overordnet er der to dimensioner ved politisk medborgerskab, nemlig deltagelse i på den ene side den demokratiske valghandling (Marshall 2003: 53-54) og på den anden side den politiske offentlighed, som især Habermas har beskrevet særligt indgående (jf. Habermas 2009). Hvor Habermas' offentlighedsteori først og fremmest beskriver et ideal for den offentlige diskussion og demokratiske deltagelse, synes Michael Schudsons beskrivelse af monitorerende medborgerskab (monitorial citizenship) imidlertid at være en mere adækvat diagnosticering af de fleste borgeres faktiske deltagelse i den politiske offentlighed. Pointen i denne optik på medborgerskab er, at borgere på grund af et tidsmæssigt underskud i hverdagen kun i begrænset omfang er direkte politisk aktive, men at de til gengæld følger med i og overvåger det politiske system fra sidelinjen og skrider til handling, når dette er nødvendigt (Schudson 1998: 310 ff.). Dermed ikke sagt, at Schudsons position afskriver enhver form for demokratisk dyd eller ansvar hos den enkelte borger - lige modsat fremhæver han, at forestillingen om den rationelle og oplyste borger allerede fra slutningen af det 19. århundrede har været og fortsat er "the most cherished ideal in the American voting experience" (ibid.: 6).

Nyhedsmedierne udgør en integreret del af Schudsons model for deltagelse i offentligheden, idet det fortrinsvis er gennem deres indhold, borgerne orienteres om samfundsrelevante og offentlige udviklinger. Der kan således argumenteres for, at ny- 
hedsmediernes status som en politisk ressource kan vurderes på baggrund af det, de i deres indhold stiller til rådighed for borgerne. Den forståelse af ressource-begrebet, som ligger til grund for denne antagelse, kan eksemplificeres med en parallel til det geologiske fagområde: Når der eksempelvis tales om, at et oliefelt udgør en ressource, sker det uafhængigt af, om råolien rent faktisk udvindes og anvendes, eller om den bliver liggende i sit underjordiske reservoir. Denne forståelsesramme overføres i denne artikel til nyhedsmediernes indhold, der ligesom råolien kan tages i brug eller lades ligge, men som ikke desto mindre står til rådighed. Hvordan den eventuelle brug er, og hvilken effekt den har i forhold til udøvelsen af politisk medborgerskab, kan jeg imidlertid ikke sige noget om på baggrund af en indholdsanalyse alene, lige så lidt som en geolog alene på baggrund af en jordboring kan sige noget om, hvordan olien fra netop det pågældende oliefelt bruges.

Tilbage står stadig spørgsmålet om, hvornår et nyhedsmedie helt konkret er en politisk ressource? Mit bud vil være, at når en politisk ressource er noget, som kan være medvirkende til at sætte borgeren i stand til at handle politisk ved at varetage sit politiske medborgerskab, må medieindhold være en politisk ressource, når det ved at være stillet til rådighed kan være medvirkende til at sætte borgeren i stand til at træffe et informeret valg ved stemmeafgivningen og til at deltage i den politiske offentlighed. Den centrale antagelse er her, at hvis borgerne får stillet information om det politiske felt til rådighed i nyhedsmediernes indhold, kan dette indhold formodes at sætte borgerne bedre i stand til at handle som politiske medborgere. Dette er dog en antagelse, som igen ikke er undersøgt empirisk i denne indholdsorienterede analyse.

Jeg vil foreslå tre parametre, som kan bruges i vurderingen af, hvorvidt et konkret nyhedsmedie og dets journalistiske indhold kan siges at udgøre en politisk ressource på baggrund af de ovenfor opridsede præmisser:

Monitorering. Dette parameter ligger i direkte forlængelse af Schudsons beskrivelse af monitorerende medborgerskab og relaterer sig helt fundamentalt til, om nyhedsmediet stiller den information til rådighed, som kan formodes at være tilstrækkelig 
til at give et overblik over den aktuelle situation. Monitorering handler om at få overblik (over det politiske system og dets aktiviteter), hvilket kan forstås som en kombination af opdatering på de seneste nyheder og sammenfatning af de vigtigste begivenheder (Hjarvard 1995: 351 ff.). Opfyldelsen af dette parameter kan måles på, i hvilken udstrækning nyhedsmediet overhovedet er orienteret mod det politiske felt og den politiske offentlighed i emnevalg og stofområde, og hvorvidt aktualitetsstof og nyhedsartikler og -indslag helt fundamentalt handler om politik.

Forståelse. Hvor det første parameter fokuserer på opdatering i og sammenfatning af nyhedsstrømmen, sigter forståelsesparametret på graden af baggrundsstof og en mere forståelsesorienteret tilgang i dækningen af aktuelle begivenheder inden for det politiske felt. Dette parameter supplerer således monitoreringsparametrets fokus på bredde ved at fokusere på dybde. Opfyldelsen af dette parameter kan måles på, i hvilken udstrækning nyhedsmediets politiske stof præsenteres i fortolkende genrer (eksempelvis i form af baggrundsartikler og -indslag) og således perspektiverer til den politiske sammenhæng, stoffet udspringer fra. Det kan desuden måles på, i hvilket omfang den politiske journalistik frem for person- og/eller processpørgsmål behandler den politiske substans og dermed præsenterer et materiale, som kan antages at gøre sit publikum klogere på baggrunden for begivenhederne inden for det politiske felt.

Adgang. Dette tredje og sidste parameter udspringer af den habermasianske opfattelse af den politiske offentlighed som samfundets centrale arena og forholder sig til, i hvilken grad nyhedsmediet muliggør, at borgerne har adgang til og kan deltage i den politiske offentlighed. Deltagelsen i den politiske offentlighed udgør en kvalitativ dimension af medborgerskab, og i et mediemættet samfund, hvor offentlig kommunikation i vid udstrækning foregår med mediernes mellemkomst, er adgang til at komme til orde i nyhedsmedierne derfor central. Opfyldelsen af dette parameter kan måles på, i hvilken udstrækning nyhedsmediet dels repræsenterer befolkningen symbolsk ved at bruge almindelige borgere som kilder i den politiske journalistik, dels lader almindelige borgere komme til orde som afsendere i opinionsstoffet. 
Det er selvsagt ikke parametre, som kan sættes på formel og vurderes som entydigt opfyldte eller det modsatte. Der er nærmere tale om delvist overlappende kontinua og om, at i jo højere grad disse parametre er opfyldt, desto mere kan et givent nyhedsmedie og dets journalistik siges at være en politisk ressource. Hvorvidt dette er tilfældet for gratisaviserne, vil jeg gennemgå nedenfor efter et kort ophold ved analysens metodologi.

\section{Metodologi}

De tre ovenfor nævnte parametre er operationaliseret ved en kvantitativ indholdsanalyse af et empirisk materiale på i alt 706 artikler (redaktionelt stof såvel som opinionsstof). Materialet stammer fra gratisaviserne metroXpress, Nyhedsavisen og Urban samt til sammenligning Morgenavisen Jyllands-Posten og tabloidavisen Ekstra Bladet. Fordelingen af materialet på aviser fremgår af Tabel 1. De valgte aviser repræsenterer forskellige avistyper og muliggør derved en sammenlignende analyse på tværs af det danske avismarked, hvor nicheaviserne dog er udeladt af omfangsmæssige hensyn. At de to betalingsaviser stammer fra samme mediehus (JP/Politikens Hus) og dermed ikke giver mulighed for at se på tværs af de store nyhedsorganisationer, skyldes, at hverken Berlingske Tidende eller B.T. (hovedaviserne i det daværende Berlingske Officin) udkom alle dage i det tidsrum, materialet stammer fra.

De 706 artikler udgør de pågældende avisers samlede politiske stof i hverdagene i uge 16 (16.-20. april) 2007. At kun aviser fra

\section{Tabel 1}

Fordeling af datamaterialets 706 analyseenheder på aviser og nyheds- og opinionsstof.

\begin{tabular}{lccccc}
\hline & $\begin{array}{c}\text { metro- } \\
\text { Xpress }\end{array}$ & $\begin{array}{c}\text { Nyheds- } \\
\text { avisen }\end{array}$ & Urban & $\begin{array}{c}\text { Jyllands- } \\
\text { Posten }\end{array}$ & $\begin{array}{c}\text { Ekstra } \\
\text { Bladet }\end{array}$ \\
\hline Nyheder & 133 & 73 & 71 & 169 & 38 \\
\hline Opinion & 22 & 23 & 16 & 94 & 67 \\
\hline Samlet & 155 & 96 & 87 & 263 & 105 \\
\hline
\end{tabular}


hverdage er inddraget, skyldes, at metroXpress og Urban heller ikke dengang udkom i weekenderne. Fordelen ved at inddrage materiale fra en sammenhængende frem for en konstrueret uge er, at udviklinger og sammenhænge i det politiske stof omfattes af det empiriske materiale. Omvendt er ulempen, at analysen kan tænkes at være mindre resistent over for de skævheder i den samlede politiske dækning, som ekstraordinære begivenheder i løbet af den udvalgte uge kan medføre.

Udvælgelsen af materialet er inspireret af Anker Brink Lunds analyser i hans bidrag til Magtudredningen, som baserede sig på „massemedierede tekster, hvori der optræder partipolitikere, f.eks. ministre, folketingsmedlemmer, kommunalpolitikere og medlemmer af Europa-Parlamentet" (Lund 2002: 20). Denne udvælgelsesstrategi har jeg i vid udstrækning kopieret i min undersøgelse, om end jeg har udvidet samplingkriteriet på to punkter, idet jeg dels inkluderer politiske aktører i en bredere forstand end Lund (og eksempelvis også opfatter interesseorganisationer, politiske meningsdannere og politisk aktive borgere som politiske aktører, i det omfang deres optræden i artiklen er orienteret imod det politiske system), dels også inkluderer opinionsstof $i$ form af eksempelvis læserbreve.

Det er en mulig fejlkilde i den kvantitative indholdsanalyse, at det samlede kodningsarbejde er udført af én person, hvorfor resultaterne er følsomme over for eventuelle forudfattede holdninger og bias hos koderen. For at imødekomme denne potentielle svaghed i metodologien er der gennemført en reliabilitetstest med genkodning af 40 tilfældigt udvalgte analyseenheder svarende til 5,7 procent af det samlede empiriske materiale på et senere tidspunkt i arbejdsprocessen (jf. Berelson 1954: 514). De kappa-værdier (Cohen 1960) for ensartetheden i kodningerne, som denne reliabilitetstest er resulteret i, står anført nedenfor i gennemgangen af analysen af de forskellige variabler, hvor der har været et element af fortolkning involveret i kodningsarbejdet. 


\section{Gratisavisernes politiske stof}

Efter disse beskrivelser af teoretisk baggrund og metodisk fremgangsmåde vil jeg nu gennemgå analysens resultater. Gennemgangen af resultaterne er struktureret efter de tre parametre, jeg definerede ovenfor: monitorering, forståelse og adgang.

\section{Monitorering}

Jo mere politisk stof en avis indeholder, desto mere information om det politiske felt må den antages at stille til rådighed for sine modtagere. Til at anskueliggøre, i hvilken grad gratisavisernes politiske stof opfylder monitoreringsparametret, har jeg derfor i første omgang analyseret gratisavisernes orientering imod og prioritering af det politiske felt ud fra den antagelse, at et emnefelts vigtighed for en avis må formodes at være proportionalt med, hvor stor en del af den pågældende avis det udgør.

Som det fremgår af Tabel 2, udgør det politiske stof langtfra hovedparten af de tre gratisaviser, om end gratisaviserne dog $\mathrm{i}$ et vist omfang må siges at være orienterede mod det politiske system i deres indhold. Det er imidlertid værd at bemærke, at andelen af spaltemillimeter, som bruges på politisk stof, er omtrent dobbelt så stor i Nyhedsavisen som i metroXpress og Urban. Til sammenligning optager kulturstoffet omtrent dobbelt så meget spalteplads som det politiske stof i alle tre gratisaviser, hvilket dog givetvis kan forklares med gratisavisernes særlige fokus på

\section{Tabel 2}

Gratisavisernes prioritering af politisk stof. Jyllands-Posten og Ekstra Bladet er ikke medtaget her, da materialet fra dem er fremskaffet fra mikrofilm, og opmåling derfor har været for ressourcekrævende til at kunne gennemføres i denne undersøgelse. Kilde til oplysninger om kulturstof: From og Kristensen 2007: 14.

\begin{tabular}{lccc}
\hline Avis & metroXpress & Nyhedsavisen & Urban \\
\hline $\begin{array}{l}\text { Andel politisk stof } \\
\text { (af avisens } \mathrm{mm}^{2} \text { totalt) }\end{array}$ & $4,8 \%$ & $10,5 \%$ & $5,5 \%$ \\
\hline $\begin{array}{l}\text { Andel kulturstof } \\
\text { (af avisens } \mathrm{mm}^{2} \text { totalt) }\end{array}$ & $11,8 \%$ & $17,6 \%$ & $10,0 \%$ \\
\hline
\end{tabular}




\section{Tabel 3}

Gratisavisernes placering af redaktionelt politisk stof på forsiden.

\begin{tabular}{lccccc}
\hline Avis & $\begin{array}{c}\text { metro- } \\
\text { Xpress }\end{array}$ & $\begin{array}{c}\text { Nyheds- } \\
\text { avisen }\end{array}$ & Urban & $\begin{array}{c}\text { Jyllands- } \\
\text { Posten }\end{array}$ & $\begin{array}{c}\text { Ekstra } \\
\text { Bladet }\end{array}$ \\
\hline $\begin{array}{l}\text { Andel af politisk } \\
\text { stof placeret på } \\
\text { forsiden (af antal } \\
\text { analyseenheder) }\end{array}$ & $11,3 \%$ & $11,0 \%$ & $5,6 \%$ & $10,1 \%$ & $2,6 \%$ \\
\hline
\end{tabular}

netop det bredt appellerende kulturstof (From og Kristensen 2007: 6 ff.).

En anden indikator for gratisavisernes prioritering af politisk stof er placeringen af det, idet placeringen af en given historie på forsiden signalerer, at netop denne historie prioriteres højt af redaktionen (hvad enten dette så skyldes hensyntagen til offentlighedens eller investorernes interesser, jf. Hjarvard et al. 2004: 21). Som det fremgår af Tabel 3, indikerer placeringen af det politiske stof i metroXpress og Nyhedsavisen, at disse gratisaviser faktisk prioriterer det politiske stof relativt højt, idet mere end hver 10. analyseenhed i de to aviser har fået en forsideplacering. Baseret på analysen af denne variabel forekommer det politiske nyhedsstof lige så vigtigt i disse to aviser som i Jyllands-Posten, mens Urban og især Ekstra Bladet ikke i samme grad fremhæver det.

Opfyldelsen af monitoreringsparametret kan ligeledes vurderes på baggrund af avisernes genrebrug.

\section{Forståelse}

Flere analyser af nyhedsformidling peger i retning af, at forklarende og fortolkende genrer såsom analyser, kommentarer og baggrundsartikler er blevet mere fremtrædende gennem de seneste årtier (Hjarvard et al. 2004: 24, McNair 2000: 61-62). Når brugen af denne form for genrer kan anvendes som en indikator i forhold til forståelsesparametret, skyldes det, at det er i artikler, som falder inden for disse genrer, at baggrundsinformation og en dybere indsigt formidles til læserne, og en analyse af gratisavisernes brug af genrer kan dermed anskueliggøre, hvordan de 


\section{Figur 1}

Brug af genrer i det politiske nyhedsstof

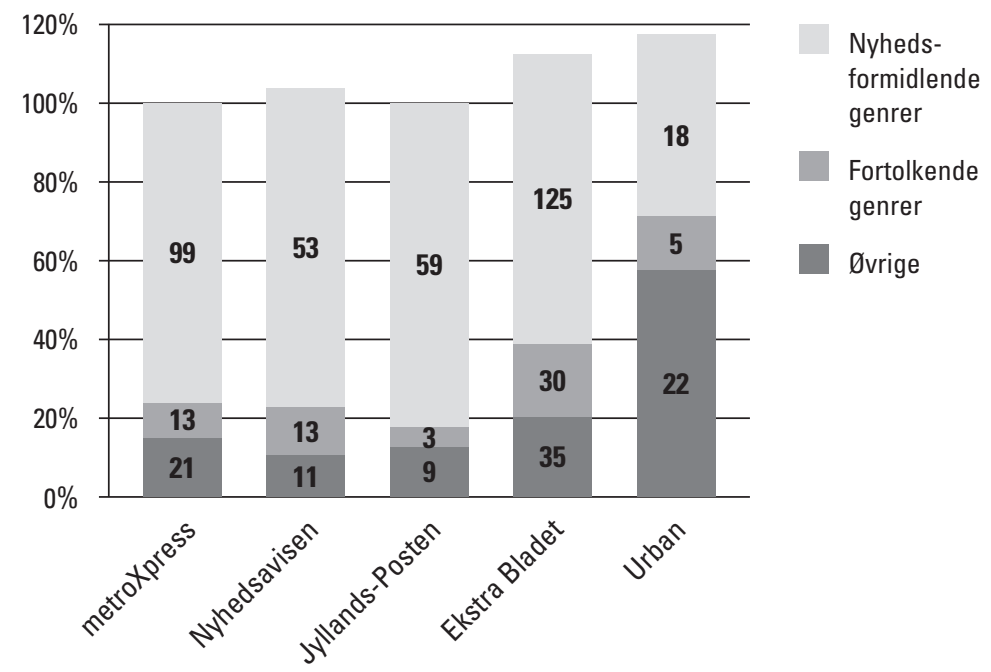

Brug af genrer i det redaktionelle stof. Nyhedsformidlende genrer: nyhed og notits. Fortolkende genrer: analyse/baggrund, politisk kommentar og anmeldelse. Øvrige: reportage, interview, portræt, større forsidehenvisning og andet. Da hver analyseenhed har kunnet kodes for op til to genrer, overstiger den akkumulerede andel af genrer for nogle avisers vedkommende 100 procent. $\mathrm{N}=516$. Kappa for ensartethed $\mathrm{i}$ kodning = 0,807 .

forholder sig til dette andet parameter. De fem analyserede avisers overordnede brug af genrer er illustreret i Figur 1.

Der er ganske stor forskel på, hvor stor en andel af gratisavisernes politisk orienterede nyhedsstof, der falder inden for de fortolkende genrer. For Nyhedsavisens vedkommende er det således 17,8 procent af artiklerne i det redaktionelle stof (13 analyseenheder), mens metroXpress og Urban med henholdsvis 9,8 (13) og 5,6 (4) procent i betydeligt lavere grad synes at forklare, fortolke eller perspektivere nyhedsstrømmen for læserne. Af gratisaviserne er det således Nyhedsavisen, som i videst udstrækning opfylder forståelsesparameteret i denne henseende. Fælles for de tre gratisaviser er imidlertid, at knap fire ud af fem af de analyseenheder, som ikke er opinionsstof, er kodet som en af de to "reneste“ nyhedsformidlende genrer, notits eller nyhed. 211 af de 277 analyseenheder (76,2 procent) i gratisavisernes nyheds- 
stof falder således inden for disse to genrer, hvorfor disse aviser generelt må siges at have et stærkt fokus på aktuelle hændelser og en ambition om at udstyre læserne med et så opdateret nyhedsbillede som muligt. Dette knytter igen an til monitoreringsparametret.

Der eksisterer på dette punkt et spændingsfelt mellem på den ene side de fortolkende genrer, som relaterer sig til forståelsen af det politiske system, og på den anden side de nyhedsformidlende genrer, som relaterer sig til monitoreringen af det politiske system. Hvor brugen af en genre fungerer positivt i forhold til opfyldelsen af det ene parameter, fungerer den altså negativt i forhold til det andet. Nøglen til at håndtere dette immanente modsætningsforhold må være, at det givne nyhedsmedie opretholder en balance mellem de to typer genrer, således at begge parametre tilgodeses i den samlede politiske dækning, som derved tilgodeser både overblik og indsigt. Hvordan denne balance konkret bør være, er et åbent spørgsmål, men hvis man vender blikket mod Jyllands-Postens brug af genrer, kan man i hvert fald få et fingerpeg om, hvordan en af de ældre og mere traditionsbundne aviser, som almindeligvis anses for at være journalistisk velfunderet, griber spørgsmålet an. Her er det interessant, at Jyllands-Posten og Nyhedsavisen benytter genretyperne i nærmest identisk udstrækning. Hvad angår de fortolkende genrer, er 17,8 procent (30 analyseenheder) af det politiske nyhedsstof i Jyllands-Posten kodet inden for disse genrer, hvilket er akkurat den samme andel som i Nyhedsavisen, mens de nyhedsformidlende genrer udgør 73,9 procent (125 analyseenheder) i Jyllands-Posten mod 74,5 procent (53) i Nyhedsavisen. For så vidt Jyllands-Postens vægtning af forklarende og nyhedsformidlende genrer kan anses for at være hensigtsmæssig i forhold til spørgsmålet om politiske ressourcer, må Nyhedsavisen således gennem sin genrebrug siges at opfylde både monitorerings- og forståelsesparametret.

En anden måde at måle forståelsesparametret på er at se nærmere på det fokus, aviserne har i deres politiske stof - et fokus, der (jf. Bro et al. 2005: 12, 54) lidt groft opdelt kan falde på processer, personer eller politik, hvoraf den sidstnævnte kategori er mest interessant i forhold til forståelsesparametret, eftersom den 


\section{Figur 2}

Fokus i det politiske nyhedsstof

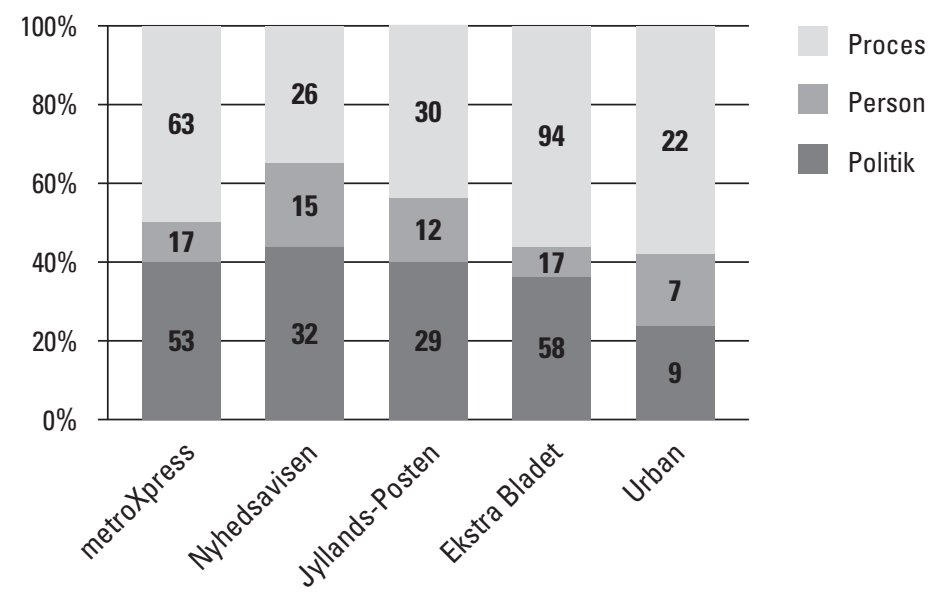

Fokus i det politiske nyhedsstof. $\mathrm{N}=484$. Kappa for ensartethed $\mathrm{i}$ kodning $=0,570$.

relaterer sig til, om artiklerne handler om det politisk substantielle i en given sag. Som det fremgår af Figur 2 har godt 4 ud af 10 af de analyserede artikler i gratisaviserne politik som deres primære fokus (41,2 procent), hvilket er noget højere end især Ekstra Bladet (23,7 procent) og i mindre grad Jyllands-Posten (34,3 procent). Forskellen gratisaviserne imellem på dette fokuspunkt er marginal, idet der her kun er udsving på ganske få procentpoint, hvorimod forholdet mellem proces- og personfokusering varierer. MetroXpress er således mere fokuseret på de politiske processer end især Nyhedsavisen (de to gratisaviser har henholdsvis 57,5 og 35,6 procent artikler med dette fokus), som til gengæld har et større fokus på personer (20,5 procent) end de to andre. Urban har omtrent lige stor fokus på proces og politik, mens godt hver syvende artikel (16,9 procent) er fokuseret på personer. Både Jyllands-Posten og Ekstra Bladet fokuserer med knap 6 ud af 10 artikler betydeligt mere på proces end gratisaviserne.

\section{Adgang}

Hvor de ovenfor gennemgåede variabler relaterer sig til avisernes opfyldelse af monitorerings- og forståelsesparametrene, kan adgangsparametret måles på to dimensioner: På den ene side al- 
mindelige borgeres adgang til det politiske nyhedsstof som kilder, hvilket kan forstås som en symbolsk repræsentation af befolkningen som sådan, og på den anden side borgernes deltagelse i opinionsstoffet.

Hvad angår borgernes rolle som kilder, kan det, når analysens empiriske materiale nu er politisk stof, næppe overraske, at netop kilder fra det politiske system og myndighederne udgør en meget stor del af de kilder, aviserne har gjort brug af. Som det fremgår af Tabel 4, falder godt halvdelen af samtlige citerede kilder således inden for denne kategori. Hvad der imidlertid er mere interessant i forbindelse med denne undersøgelse, så optræder almindelige borgere relativt ofte som kilder i det politiske nyhedsstof. Ud af de i alt 429 type-kodede kilder i gratisaviserne er 30 (7 procent) således almindelige borgere, hvilket godt nok er en anelse lavere end i Jyllands-Posten, men betydeligt højere end i Ekstra Bladet, hvor kun en enkelt borger optræder i den politisk orienterede nyhedsjournalistik i løbet af de fem analyserede dage. Der er imidlertid stor forskel på, i hvor høj grad de tre gratisaviser inddrager almindelige borgere i deres politiske nyhedsstof, idet det i Nyhedsavisen er knap hver 10. kilde, som er almindelig borger, mens det i metroXpress er hver 13. og i Urban

\section{Tabel 4}

Kildetyper i avisernes politiske nyhedsstof. Politiske kilder/myndighedskilder: landspolitiker, regionalpolitiker, kommunalpolitiker, politisk parti, udenlandsk politiker/parti/myndighed og embedsmand/ministerium/off. myndighed. $\mathrm{N}=786$. Kappa for ensartethed $\mathrm{i}$ kodning $=0,826$.

\begin{tabular}{|c|c|c|c|c|c|}
\hline Avis & $\begin{array}{l}\text { metro- } \\
\text { Xpress }\end{array}$ & $\begin{array}{l}\text { Nyheds- } \\
\text { avisen }\end{array}$ & Urban & $\begin{array}{l}\text { Jyllands- } \\
\text { Posten }\end{array}$ & $\begin{array}{l}\text { Ekstra } \\
\text { Bladet }\end{array}$ \\
\hline Kilder i alt & 181 & 126 & 122 & 303 & 54 \\
\hline $\begin{array}{l}\text { - heraf politiske } \\
\text { kilder/myndig- } \\
\text { hedskilder }\end{array}$ & $\begin{array}{c}93 \\
(50,8 \%)\end{array}$ & $\begin{array}{c}53 \\
(42,1 \%)\end{array}$ & $\begin{array}{c}65 \\
(53,3 \%)\end{array}$ & $\begin{array}{c}165 \\
(54,5 \%)\end{array}$ & $\begin{array}{c}29 \\
(53,7 \%)\end{array}$ \\
\hline $\begin{array}{l}\text { - heraf } \\
\text { almindelige } \\
\text { borgere }\end{array}$ & $\begin{array}{c}14 \\
(7,7 \%)\end{array}$ & $\begin{array}{c}12 \\
(9,5 \%)\end{array}$ & $\begin{array}{c}4 \\
(3,3 \%)\end{array}$ & $\begin{array}{c}28 \\
(9,2 \%)\end{array}$ & $\begin{array}{c}1 \\
(1,9 \%)\end{array}$ \\
\hline
\end{tabular}


blot hver 30. Igen kan det diskuteres, hvor tærsklen er, og hvornår andelen af kilder, som er almindelige borgere, er tilstrækkeligt stor til, at adgangsparametret kan siges at være opfyldt - blandt andet fordi en omfattende brug af borger-kilder kan tænkes at gå ud over den substantielle forankring, som eksempelvis eksperter og politikere med deres baggrundsviden og indsigt kan give det politiske nyhedsstof. Adgangsparametrets opfyldelse kan således stå i et modsætningsforhold til forståelsesparametrets prioritering af baggrundsstof og formidling af indsigt. Hvordan den ideelle prioritering og anvendelse af forskellige kildetyper end er, må Nyhedsavisen på baggrund af brugen af almindelige borgere som kilder siges at være den af de tre gratisaviser, som i videst udstrækning opfylder adgangsparametret ved at give borgerne adgang til spalterne, mens metroXpress gør det i lidt ringere grad og Urban i meget ringere grad.

Hvis man går videre til opinionsstoffet, er der stor forskel på, hvordan de analyserede avistyper prioriterer det relativt, idet denne stoftype sammenlagt udgør blot 18 procent af analyseenhederne i gratisaviserne mod 35,7 procent i Jyllands-Posten og ikke mindre end 63,8 procent i Ekstra Bladet. Internt blandt gratisaviserne er der dog også forskelle. Nyhedsavisen har således med 24 procent relativt mere opinionsstof end både Urban (18,4 procent) og metroXpress (14,2 procent), men fælles for dem er altså, at selvom det er til stede, fylder det noget mindre end i morgen- og tabloidavisen. Opinionsstoffet prioriteres simpelthen lavt i gratisaviserne i forhold til nyhedsstoffet.

Af de 222 analyseenheder, som er fundet i opinionsstoffet, er de 194 læserbreve, og at andelen er så høj, er umiddelbart positivt i forhold til adgangsparametret, idet det på grund af blandt andet det relativt korte format må formodes at være denne genre inden for opinionsstoffet, hvor den almindelige borger har bedst mulighed for at komme til orde. Det i denne sammenhæng mest interessante aspekt ved opinionsstoffet er derfor, hvem der har forfattet de læserbreve, som bliver bragt; i jo højere grad, det er almindelige borgere, der står som afsendere, i desto højere grad kan adgangsparametret siges at være opfyldt. 


\section{Figur 3}

Forfattere til politiske læserbreve

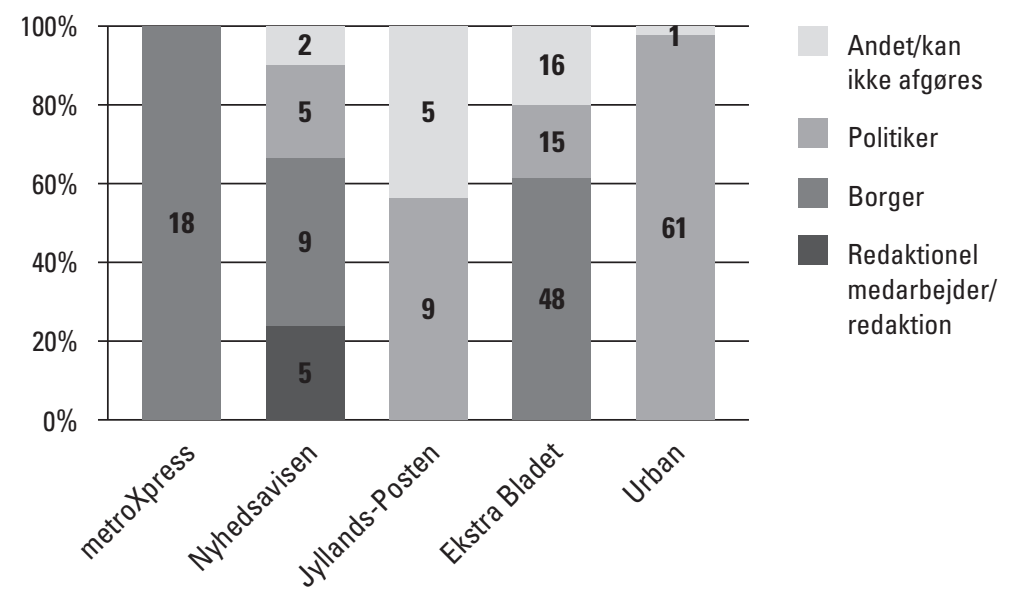

$\mathrm{N}=$ 194. Kappa for ensartethed $\mathrm{i}$ kodning $=1,000$.

På tværs af de fem aviser i analysen er ikke mindre end 74,7 procent af læserbrevene forfattet af almindelige borgere, mens det for gratisavisernes vedkommende er lidt lavere med en andel på 67,9 procent (jf. Figur 3). I den begrænsede udstrækning, gratisaviserne bringer læserbreve, har borgere således gode muligheder for at komme til orde - især i metroXpress, som de fem analyserede dage udelukkende bringer læserbreve forfattet af almindelige borgere.

Af de analyserede aviser er Nyhedsavisen den, som i mindst omfang lader almindelige borgere komme til orde i opinionsstoffet, idet blot omtrent 2 ud af 5 læserbreve (9 af 21; 42,9 procent) er forfattet af denne gruppe, mens Urban med knap 2 ud af 3 læserbreve ( 9 af 14; 64,3 procent) ligger en anelse højere end JyllandsPosten på dette punkt. For Ekstra Bladets vedkommende gælder det, at kun 1 ud af 65 læserbreve ikke er forfattet af almindelige borgere. Det er samtidig bemærkelsesværdigt, hvor stor forskel der er på kvantiteten af læserbreve mellem på den ene side gratisaviserne og på den anden side Jyllands-Posten og Ekstra Bladet. Jyllands-Posten har eksempelvis omtrent halvanden gang så mange læserbreve som gratisaviserne tilsammen i den analy- 
serede uge, og hvor de to betalte aviser begge har 2-3 sider med opinionsstof dagligt, har Nyhedsavisen en og metroXpress og Urban hver knap en halv. Mens Jyllands-Posten og Ekstra Bladet i gennemsnit bringer henholdsvis 15,8 og 12,4 politisk orienterede læserbreve om dagen, bringer gratisaviserne metroXpress, Nyhedsavisen og Urban blot henholdsvis 3,6, 4,2 og 2,8. Alene disse forhold må alt andet lige betyde, at den almindelige borgers muligheder for at få adgang til at deltage i den politiske offentlighed er markant bedre i Jyllands-Posten og Ekstra Bladet end i de gratis alternativer.

\section{Konklusion}

Det kan diskuteres, om disse tre parametre alene er udtømmende i forhold til at vurdere, om gratisaviserne udgør en politisk ressource. For det første kan man forestille sig, at udsigelseskraften $\mathrm{i}$ analyse ville blive styrket, hvis parametre som eksempelvis tilgængelighed (målt i lixtal og anvendelse af illustrationer) eller bidrag til den journalistiske fødekæde (i kraft af originalt produceret journalistisk materiale) blev inddraget og undersøgt. Når disse to yderligere parametre alligevel ikke er inddraget her, skyldes det, at jeg i analysen udelukkende har villet forholde mig til, hvad gratisaviserne stiller til rådighed for borgerne - ikke hvordan det formidles, eller hvordan det indgår i et større kredsløb inden for nyhedsinstitutionen. For det andet kan fremgangsmådens egnethed diskuteres, altså om man overhovedet kan undersøge en problemstilling som denne ved at opstille absolutte målekriterier, eller om en kvalitativ analyse af mere eksplorativ karakter havde været mere hensigtsmæssig. En sådan kvalitativ tilgang ville utvivlsomt generere værdifulde indsigter i en videre analyse, men når den er fravalgt i denne sammenhæng, bunder det i et ønske om at vurdere gratisaviserne på baggrund af en systematisk sammenligning med andre avistyper, og netop den konkrete sammenligning er med til at kvalificere analysens resultater.

Det kan på baggrund af de kvantitative data konkluderes, at gratisaviserne under ét først og fremmest varetager den monitorerende funktion, som ligger i forlængelse af Schudsons beskri- 
velse af det monitorerende medborgerskab. Det er således dette parameter, som alle de tre analyserede gratisaviser i videst udstrækning opfylder, og i forlængelse heraf kan det konkluderes, at gratisaviserne i hvert fald i forhold til at stille informationer om aktuelle udviklinger inden for det politiske felt og system til rådighed for læserne er en politisk ressource. Gratisaviserne kommer helt fundamentalt omkring de forskellige politiske begivenheder, der finder sted i den pågældende uge. Selvom Jyllands-Postens politiske stof tæller både flere artikler og især mere opinionsstof, tilbyder gratisaviserne - først og fremmest Nyhedsavisen - deres læsere en lige så god nyhedsopdatering som morgenavisen, mens de synes at varetage denne funktion markant bedre end Ekstra Bladet. Hvor gratisaviserne refererer langt hovedparten af de vigtigste begivenheder i det politiske system i den analyserede uge, består tabloidavisens politiske stof således altovervejende af læserbreve om muslimske kvinders ret til at bære tørklæder, satirisk kritik af forskellige politiske aktører og sensationalistiske politik-relaterede nyheder såsom „Gangster dræber borgmester“ (Ekstra Bladet, onsdag 18. april 2007, 1. sektion, side 18), hvilket antyder, at tabloidavisen tilstræber at varetage en underholdnings- nærmere end en opdaterings- og oplysningsorienteret funktion.

Hvad angår forståelsesparameteret, opfylder alle tre gratisaviser det i tilstrækkelig grad til, at udviklingerne i det politiske system gøres relativt begribelige for læserne, men det fremstår ikke som en styrkeposition for nogen af dem. Det er således kun Nyhedsavisen, som i vid udstrækning tager de fortolkende genrer i brug, mens en supplerende kvalitativ læsning af materialet (som der imidlertid ikke er plads til at referere yderligere her) viser, at alle tre gratisaviser i et vist omfang lader forklarende baggrundsoplysninger indgå i nyhedsformidlende artikler. Dette sker dog ikke på et niveau, hvor det kan konkurrere med den baggrundsviden, der stilles til rådighed for læserne i Jyllands-Posten, hvilket især eksemplificeres ved en temasektion i morgenavisen i anledning af det franske præsidentvalg, men også kommer til udtryk i den daglige dækning af det politiske område.

Endelig er adgangsparameteret det af de tre parametre, som gratisaviserne i det gennemgåede materiale er længst fra at op- 
fylde, hvilket først og fremmest skyldes den meget begrænsede tilstedeværelse af borger-forfattet opinionsstof i gratisaviserne. Omfanget af opinionsstoffet i det hele taget vidner om en begrænset ambition fra gratisavisernes side om at facilitere deltagelse i den politiske offentlighed, som både Habermas og også Schudson (1998: 12) ellers angiver som en central komponent af politisk medborgerskab, og taget i betragtning at kun en mindre del af læserbrevene i Nyhedsavisen og Urban er forfattet af almindelige borgere, forstærkes dette indtryk. Anderledes forholder det sig med Jyllands-Posten og Ekstra Bladet, der begge i et betydeligt omfang bringer opinionsstof forfattet af almindelige borgere, og som således konstruerer et mere inklusivt forum i den politiske offentlighed.

Med et stærkt fokus på opdatering af læserne og et ikke ubetydeligt aspekt af baggrundsinformation - men samtidig også begrænsede muligheder for almindelige borgeres adgang til nyhedsmediernes indhold - må gratisaviserne således i overvejende grad siges at udgøre en politisk ressource, når man måler på de tre i denne artikel opstillede parametre. De synes imidlertid ikke at være en politisk ressource, der ville kunne træde i stedet for det, en morgenavis som Jyllands-Posten tilbyder sine læsereforståelses- og adgangsparametrene opfyldes i for ringe grad til, at de kan udgøre et egentligt alternativ - men dog en, som i betydeligt højere grad end Ekstra Bladet kan tænkes at være medvirkende til at klæde læserne på til at udøve politisk medborgerskab. I forhold til nyhedsmediernes placering i det politiske demokrati kan gratisaviserne således være et supplement til morgenaviserne, mens de målt alene på det politiske stof udmærket ville kunne erstatte tabloidaviserne.

\section{REFERENCER}

Advice Analyse og Strategi (2005): Hovedrapport: Danskernes avislcesning, København: Advice Analyse og Strategi.

Bakker, Piet (2007a): “Free daily journalism - anything new?”, Journalistica, nr. 4, pp. 22-32.

Bakker, Piet (2007b): “Free Newspaper Readership”, paper fra Worldwide 
Readership Research Symposium 2007, 21.-24. oktober 2007, Wien.

Berelson, Bernard (1954): “Content Analysis” i Lindzey, Gardner (red.)

(1954): Handbook of Social Psychology. Volume I: Theory and Method, Cambridge: Addison-Wesley Publishing Company.

Bro, Peter, Rasmus Jønsson, Søren Schultz Jørgensen \& Poul Anders Pedersen (2005): Mediernes valgkamp - et forsknings- og formidlingsprojekt om folketingsvalget $i$ 2005, København: Modinet.

Cohen, Jacob (1960): "A Coefficient of Agreement for Nominal Scales" i Educational and Psychological Measurement, 20. årgang, nr. 1, pp. 3746.

Couldry, Nick, Sonia Livingstone \& Tim Markham (2007): Media Consumption and Public Connection: Beyond the Presumption of Attention, Hampshire: Palgrave Macmillian.

From, Unni og Nete Nørgaard Kristensen (2007): Gratis kulturstof-kultur i gratisaviserne, paper fra 18. Nordiske Medieforskerkonference, 16.-19. august 2007, Helsinki.

Giddens, Anthony (1979): Central Problems in Social Theory. Action, structure and contradiction in social analysis, Berkeley: University of California Press.

Habermas, Jürgen [1962] (2009): Borgerlig offentlighed, København: Informations Forlag.

Hjarvard, Stig (1995): Internationale tv-nyheder, København: Akademisk Forlag.

Hjarvard, Stig, Nete Nørgaard Kristensen og Mark Ørsten (2004): Mediernes doekning af invasionen af Irak 2003, København: Modinet.

Kammer, Aske (2009): Gratisaviserne som politisk ressource, upubliceret speciale, København: Institut for Medier, Erkendelse og Formidling, Københavns Universitet. Tilgængeligt på www.askekammer.dk.

Lund, Anker Brink (2002): Den redigerende magt. Nyhedsinstitutionens politiske indflydelse, Århus: Aarhus Universitetsforlag.

McNair, Brian (2000): Journalism and Democracy. An evaluation of the political public sphere, London: Routledge.

Marshall, Thomas H. [1950] (2003): Medborgerskab og social klasse, København: Hans Reitzels Forlag.

Minke, Kim (2008): Aviskrigen. Dagblade i overlevelseskamp, Valby: Borgen.

Schudson, Michael (1998): The Good Citizen. A History of American Civic Life, New York: The Free Press. 
Skyum-Nielsen, Rune, Rasmus Karkov, Morten Runge \& Niels Holst (2009): Alt går efter planen. Sagaen om Nyhedsavisen, København: Politikens Forlag.

Wadbring, Ingela (2003): En tidning i tiden? Metro och den svenska dagstidningsmarknaden, Göteborg: Institutionen för journalistik och masskommunikation, Göteborgs universitet.

Wadbring, Ingela (2007a): „Konsekvenser av dagliga gratistidningar på marknaden - svenska erfarenheter“, Mediekultur, nr. 42/43, pp. 86101.

Wadbring, Ingela (2007b): “The Role of Free Dailies in a Segregated Society”, Nordicom Review, Jubilee Issue 2007, pp. 135-147. 


\section{English Abstract}

\section{Free Daily Newspapers as a Political Resource}

\section{ASKE KAMMER}

Even though the free daily newspapers have become some of the most read newspapers in Denmark, the Danish research (especially from a content analytical perspective) into this kind of newspapers is still very limited. This article presents the results of a quantitative content analysis of the political content in free daily newspapers in comparison with the corresponding content in a broadsheet and a tabloid newspaper. The analysis is carried out within a framework of the three parameters 'monitoring', 'understanding' and 'access'; three parameters that can be taken - it is argued - as an expression of whether a news medium could be understood as a political resource. 